\title{
Remediation of Chromium Toxicity by Biochar, Poultry Manure and Sewage Sludge in Rice (Oryza sativa) Crop
}

\author{
Jiten Kumar Behera ${ }^{*}$, P. K. Sharma ${ }^{1}$, Tusarkanta Behera ${ }^{1}$, \\ Ramya Krishna Koka ${ }^{1}$ and Arvind ${ }^{1}$
}

Department of Soil Science and Agricultural Chemistry, Institute of Agricultural Sciences,
Banaras Hindu University, India

*Corresponding author

\begin{abstract}
A B S T R A C T
The accumulation of $\mathrm{Cr}$ in soil is a major concern because of its possible phytotoxicity or increased movement of metals into food chain and the potential

for surface and ground water contamination. Excessive metal accumulation in contaminated soil can result in decrease in soil microbiological activities, soil fertility and overall soil quality which may lead to reduction in yield. With Three levels of chromium concentration $(0,25,50 \mathrm{ppm})$ with and without organic amendments like Biochar, Poultry Manure and sewage sludge a pot culture experiment was conducted taking paddy as a test crop with an objective to study the remediation effect of these organic amendment on Chromium toxicity by assessing different growth parameters and yield attributes of Rice plant. Results shows that there is a significant increase in the growth parameters like plant height, number of tillers/hills, productive tillers/hill, number of grains/panicles, chlorophyll content, panicle length, test weight, straw yield, grain yield and harvest index with application of Biochar, Poultry manure \& Sewage sludge. Hence organic amendment like Biochar, Poultry manure and sewage sludge play a great role in remediation of chromium contaminated soil and increase ability of rice crop to withstand Cr toxicity up to 50ppm.
\end{abstract}

Keywords

Rice, Chromium,

Growth, Yield,

Biochar, Poultry

manure, Sewage

sludge

Article Info

Accepted:

15 February 2020

Available Online:

10 March 2020

\section{Introduction}

Most of the agronomic plant suffer in 0.5 to $5.0 \mathrm{mg} \mathrm{mL}-1$ range of $\mathrm{Cr}$ concentration.in nutrient solution and $5-100 \mathrm{mg} \mathrm{kg}^{-1}$ in soil (Ali et al., 2013; Chrysostom et al., 2012). Recently, the use of a variety of organic and inorganic amendments has attained a considerable attention for remediation of heavy metal-contaminated soils (Usman et al., 2013; Almaroai et al., 2014; Adrees et al., 2015; Rehman et al., 2015; Rizwan et al., 2016a).

Organic and inorganic amendments are used for immobilization of metals in the soils. 
Through the formation of stable compounds with organic ligands, surface precipitation and ion exchange, organic amendments generally immobilize heavy metals (Kumpiene et al., 2008; Ahmad et al., 2011a). Moreover, organic amendments may enhance the soil fertility and microbial activity, leading to the amelioration of the soil quality as a whole. Beneficial effect of amendments like biochar, poultry manure \& sewage sludge also ascribed to increased microbial activity which might have helped in reduction of the toxic form $\left(\mathrm{Cr}_{6}^{+}\right)$to non-toxic form $\left(\mathrm{Cr}_{3}{ }^{+}\right)$by microbial activity, by acting as electron donors, and $\mathrm{O}_{2}$ level of the soil is lowered thereby creating reducing conditions.

Role of organic amendments is to reduce the toxicity of $\mathrm{Cr}$. This improvement in yield could be mainly attributed due to the reduction in the bioavailability of $\mathrm{Cr}$ and thus reduce toxic effects of $\mathrm{Cr}$ in the soil. Bioavailability of metal in the soil environment and soil particles is said to be the fraction of the total metal in the interstitial pore water that is available to the receptor organism. More specifically, it refers to the biologically available fraction (or pool) that can be taken up by an organism and can react with its metabolic machinery.

Biochar application into agricultural soil has recently attracted attention due to its potential agronomic, economic, and environmental benefits. Biochar is a carbon $(\mathrm{C})$ rich material produced by pyrolyzing waste biomass between 250 and $900{ }^{\circ} \mathrm{C}$ under continuous flow of nitrogen or anoxic conditions. Examples of waste biomass used for biochar include hard woods, rice straw, rice husks, bamboo, wheat straw, peanut hulls, poultry litter, corn Stover, bamboo and animal manures. Amending the soil with biochar has increasingly attracted widespread attention for two reasons. First, because of its chemical stability, its suitability for sequestrating $\mathrm{C}$ in soil. Secondly, it is a good soil conditioner as it improves soil fertility and growth of the plant by supplying and retaining nutrients. In addition, it reduces the Phyto availability of heavy metals, minimize the bioavailability of organic contaminants to earthworms, microbes, and plants, due to its high porosity, large surface area, and associated high sportive capacity

For these reasons, application of biochar is done in degraded land to promote restoration process. Biochar often has an increased, negatively charged surface area compared to soil and can be enriched in nutrients. Thus, upon amendment to soil biochar may increase the cation exchange capacity, $\mathrm{pH}$, water holding capacity, and decrease bulk density Biochar has been reported to have considerable agronomic values for enhancing crop production.

As per Livestock Census, 2003 the poultry population in India is 489 million and the manure availability is estimated to be 12.1 million tones. The percent nutrient composition of poultry manure is $2.2-3 \% \mathrm{~N}$, $1.8 \% \mathrm{P}$ and $0.5-1 \% \mathrm{~K}$. poultry manure can be used as an organic amendment for phytoremediation of Chromium as it helps in biotransformation of $\mathrm{Cr}$ from its higher to lower oxidative state.

Sewage refers to the used-up water from towns and cities collected though a drainage system. It consists of solid and liquid excreta and liquid wastes from kitchen and bath rooms. It also contains animal vegetable and mineral matter in suspension, solution and colloidal state. It is the mineral matter that makes the purification difficult while sludge is the water drained from the kitchens, bathrooms and drainage water of the streets (open canal). The use of sewage sludge in reclamation processes contributes to the possibility of valuable elements recovery, for 
example, nitrogen, phosphorus, and other nutrients which are important for plant growth. The contents of individual components in sewage sludge result from the processes of wastewater treatment and the composition of effluent.

The use of sewage sludge for remediation has limitation due to the presence of hazardous substances, microorganisms in sewage sludge, and pathogenic micropollutants and undesirable odour. Despite such limitations, sewage sludge improves soil structure by the generation of large amounts of humus. This is the reason why sewage sludge plays an important role in the phytoremediation. In the heavy metal binding process, both inorganic substances (sulfides, phosphates, hydroxides and oxides of non-crystalline iron and aluminum, and manganese) and organic substances (living microorganisms, organic and mineral remains of dead organic compounds) are involved. Important mechanism for binding sewage sludge by heavy metals are ion exchange, precipitation and co-precipitation reactions, and adsorption of contaminants on the outer and inner surface of minerals. Sometimes the heavy metal present in sewage sludge has a positive effect on the growth of the microbial biomass and microorganisms present in the soil. Manurial value of sewage sludge is $3.5 \% \mathrm{~N}-1.0 \% \mathrm{P}_{2} \mathrm{O}_{5}$ -0.5 to $1.0 \% \mathrm{~K}_{2} \mathrm{O}$.

Rice is a staple food crop and a primary food source for $50 \%$ of the world's population (Wang et al., 2013; Ramzani et al., 2016). At present, soil contamination of heavy metals including $\mathrm{Cr}$ renders a great threat to rice production and subsequently affects food safety. High $\mathrm{Cr}$ concentration in soil is toxic to rice, resulting in reduced growth, yield, and dry matter production (Qiu et al., 2010). In rice, most of the $\mathrm{Cr}$ was accumulated in roots, but still, a significant fraction can be transported into above ground tissues, including grains, which causes a health issue to human via food chain (Qiu et al., 2011). However very few comparative studies have been performed so far and the choice of a particular organic amendment in assisted phytostabilization strategies often remain empirical (Hattab et al., 2015). So, for remediation of chromium toxicity in rice, we have used certain organic amendments like biochar, poultry manure $\&$ sewage sludge.

\section{Materials and Methods}

With Three levels of chromium concentration $(0,25,50 \mathrm{ppm})$ with and without organic amendments like Biochar, Poultry Manure and sewage sludge a pot culture experiment was conducted in Net house of the Department of Soil Science and Agricultural Chemistry, Institute of Agricultural Sciences taking paddy as a crop with an objective to study the remediation effect of these organic amendment on different growth parameters and yield attributes of Rice plant. The pots were irrigated up to field capacity and moisture level is maintained. Pots were treated with required amount of $\mathrm{Cr}$ through potassium dichromate $\left(\mathrm{K}_{2} \mathrm{Cr}_{2} \mathrm{O}_{7}\right)$ i.e. $\mathrm{Cr}(\mathrm{VI})$, with three different levels like $(0,25,50$ $\mathrm{mg} / \mathrm{kg}$ soil) and maintained contamination for 15 days. After 15 days of application of chromium, the organic amendments like Biochar i.e., as $25 \mathrm{gm} / 10 \mathrm{~kg}$ soil Sewage sludge $(50 \mathrm{~g} / 10 \mathrm{~kg}$ soil $) \&$ poultry manure $(5 \mathrm{~g} / 10 \mathrm{Kg})$ applied to the soil and thoroughly mixed well. Incubation of pot was done along with organic amendment and after watering upto field capacity five four week oldseedlings were transplanted per pot. Uniform dose of NPK was given to pots. The crop was grown up to maturity. All growth parameters, yield attributes and yield were recorded during the crop growth period.

With the help of meter scale, the height of plants was measured at 30, 60 and 90 days after transplanting from the base of the plant to the tip of the upper most fully opened leaf. 
With the use of chlorophyll meter in SPAD units, Chlorophyll content of the leaves was measured at 30, 60 and 90 days after transplanting. After panicle emergence, the height was measured up to the tip of the panicle. Number of tillers/hills was counted from each pot at 30, 60 and 90 days after transplanting total tillers/hill and productive tillers/hill from each pot was computed. By choosing five panicles randomly selected from plants in each pot average length of panicle was noted. Grains of five panicles of randomly selected from each pot were separated and counted and their mean value expressed as average grains per panicle as number of filled grains and number of unfilled grains. Grain samples were taken from the threshed and cleaned produce of each pot and 1000 grains were counted and weighed.

\section{Results and Discussion}

Effect of biochar, poultry manure \& sewage sludge on growth parameters of rice in chromium contaminated soil

\section{Plant height (cm)}

The data of total plant height of rice was recorded at 30 DAT, 60 DAT, 90 DAT. The height of rice plant in Cr-contaminated soil with and without organic amendment are presented in Table 1. Plant height increases up to 90DAT and thereafter decreases as shown in the data observed. Plant height was significantly affected by different levels of chromium at all growth stages. With increase in the chromium concentration $(0,25,50)$ ppm the plant height has decreased. Nagarajan in 2014 reported similar type of results.

There is significant increase in plant height (30 DAT) on addition of Organic amendments like biochar, poultry manure \& sewage sludge as compared to control pots. The highest plant height (54.67) was found in treatment $\mathrm{Cr} 0$ +biochar followed by the treatment $\mathrm{Cr} 0+\mathrm{PM}$ i.e., (54.33). On the other hand, the lowest values of these parameters were obtained from control pot with treatment Cr50 (47.33). The similar trend was noticed with plant height at 60 DAT and 90 DAT except a slight increase in plant height and there after a decline in height observed. Interaction effect of chromium with organic amendments showed on -significant on plant height.

Due to an adequate supply of nutrients by fertilizers and organic amendment there was increase in plant height. The availability of nutrients increased by improving important soil properties given by Ganal and Singh (1988), Singarum (1994). In the absence of any organic amendments, the rice growth was decreased due to the toxicity of Cr VI.

\section{Chlorophyll Content (SPAD)}

The data of chlorophyll was recorded by SPAD at different observation days presented in Table 2. A perusal of data presented that chlorophyll content increased slowly from 30 to 60 DAT and there after a gradual decline was observed at 90 DAT and maturity.

It is apparent from the data that chlorophyll content was significantly affected by different chromium levels at all growth stages. Data shoes that as the level of chromium increases from 0 to 50 the amount of chlorophyll content decreases respectively. oxidative stress is induced by more concentration of chromium, which involves induction of lipid peroxidation in plants that cause severe damage to cell membranes. The oxidative stress is induced by chromium initiates the degradation of photosynthetic pigments which causes a decline in growth of the plant. High chromium concentration can disturb the 
chloroplast ultra-structure there by disturbing the photosynthetic process. Cr stress is one of the important factors that affect photosynthesis in terms of $\mathrm{CO} 2$ fixation, electron transport, photophosphorylation, and enzyme activities said by Clijsters and Van Assche (1985).

The Chromium toxicity in plants occurs by inhibiting the growth more or less, showing chlorosis. High chromium concentration inhibits photosynthesis and seriously inhibits the root growth reported by Dheeba et al., (2012).

The results of the pot experiments showed that chlorophyll content rice was significantly affected due to the application of organic amendments. The highest chlorophyll content (39.51) was observed with treatment $\mathrm{Cr} 0+$ biochar followed by treatment $\mathrm{Cr} 0+\mathrm{SS}$ (38.83). Plants grown on soil without any amendments at $\mathrm{Cr} 50$ had shown yellowing of leaves. The application of Biochar, Poultry Manure \& Sewage sludge resulted in a significantly highest chlorophyll content of rice. A similar trend followed in 60DAT but during 90 DAT and maturity gradual decline in chlorophyll content due to toxicity effect of $\mathrm{Cr}$ VI. The interaction effect between chromium concentration levels and amendments on chlorophyll content was found on- significant in all growth stages. The Biochar application increased the chlorophyll $\mathrm{a}, \mathrm{b}$, total chlorophyll, and carotenoid concentrations as compared to control treated with heavy metals without any amendment as reported by Younis et al., (2016)

Effect of biochar, poultry manure \& sewage sludge on yield attributes of rice in chromium contaminated soil

\section{Number of tillers hill ${ }^{-1}$}

The data of total tillers per hill and productive tillers per hill was recorded at different observation days presented in Table 3. A perusal of data presented that the number of tillers per hill increased slowly from 30 to 60 DAT and there after a gradual decline was observed. Different levels of chromium generally affect the tiller no. As the chromium concentration increases there was a decrease in number of total tiller and productive tiller per hill as shown in the table 4. Similar results like Cr-treated rice plants showed stunted growth and produced less number of tillers and leaves compared to counterparts grown in control has reported by Ahmad et al., (2011).

The results of the pot experiments showed that a number of tillers per hill of rice and productive tillers per hill were significantly affected due to the application of organic amendments. The highest total tillers hill-1 (13.67) and productive tillers per hill (12.33) was observed in all control pots of $\mathrm{Cr} 0+$ biochar followed by $\mathrm{Cr} 0+\mathrm{SS}$ in total (12.667) and $\mathrm{Cr} 0+\mathrm{PM}$ in productive (11) tillers per hill. The application of biochar, poultry manure \& sewage sludge resulted in a significantly greater number of tillers per hill and productive tillers/hill of rice. Generally, because of supply of better micronutrient by organic sources resulted in better tillering. Application of sewage sludge biochar (SSBC) results in increase in no of tillers as reported by Khan et al., in 2013.

\section{Panicle length $(\mathrm{cm})$}

The length of the panicle is generally influenced by different chromium concentration and addition of various organic amendment. Data was collected regarding length of panicle which is represented in Table 4. The results showed that plant has slight variations and can withstand with an increase in the levels of chromium up to concentration $\mathrm{Cr} 25$ in control and with use of amendments rice can withstand up to treatment $\mathrm{Cr} 50$. 
Table.1 Effect of biochar, poultry manure and sewage sludge on plant height $(\mathrm{cm})$ of rice in chromium contaminated soil

\begin{tabular}{|l|l|l|l|}
\hline Treatments & \multicolumn{1}{|c|}{ 30 DAT } & 60DAT & 90DAT \\
\hline Cr 0 & 51.667 & 75.667 & 91.067 \\
\hline Cr 25 & 48.667 & 75.333 & 90.867 \\
\hline Cr 50 & 47.333 & 74 & 90.333 \\
\hline Cr 0 + biochar & 54.667 & 79.333 & 96.067 \\
\hline Cr 25 + biochar & 52.333 & 78.333 & 95.3 \\
\hline Cr 50 + biochar & 51 & 78 & 94.767 \\
\hline Cr 0 + PM & 54.33 & 78.667 & 96.3 \\
\hline Cr 25 + PM & 52.667 & 77 & 95.5 \\
\hline Cr 50 + PM & 50 & 76.667 & 92.4 \\
\hline Cr 0 + SS & 53.333 & 78.333 & 96.3 \\
\hline Cr 25 + SS & 51 & 77.667 & 93.333 \\
\hline Cr 50 + SS & 49.333 & 77 & 95.1 \\
\hline CD & 3.629 & N/A & N/A \\
\hline SE(m) & 1.236 & 1.255 & 2.176 \\
\hline SE(d) & 1.748 & 1.774 & 3.078 \\
\hline CV & 4.168 & 2.816 & 4.014 \\
\hline
\end{tabular}

Table.2 Effect of biochar, poultry manure \& sewage sludge on chlorophyll content (SPAD) of rice in chromium contaminated soil

\begin{tabular}{|l|l|l|l|}
\hline treatment & 30DAT & 60DAT & 90DAT \\
\hline Cr 0 & 36.727 & 32.73 & 25.67 \\
\hline Cr 25 & 34.667 & 31.19 & 25.273 \\
\hline Cr 50 & 33.167 & 28.1 & 19.33 \\
\hline Cr 0 + biochar & 39.513 & 35.13 & 27.73 \\
\hline Cr 25 + biochar & 37.333 & 33.73 & 24.67 \\
\hline Cr 50 + biochar & 35.333 & 31.4 & 21.667 \\
\hline Cr 0 + PM & 38.18 & 33.73 & 26.59 \\
\hline Cr 25 + PM & 35.44 & 32.47 & 23.1 \\
\hline Cr 50 + PM & 34.84 & 30.44 & 20.29 \\
\hline Cr 0 + SS & 38.833 & 34.29 & 27 \\
\hline Cr 25 + SS & 36.667 & 33.13 & 23.54 \\
\hline Cr 50 + SS & 34.667 & 31.667 & 20.96 \\
\hline CD & 1.479 & 1.012 & 2.751 \\
\hline SE(m) & 0.504 & 0.345 & 0.937 \\
\hline SE $(\mathbf{d})$ & 0.712 & 0.488 & 1.325 \\
\hline CV & 2.404 & 1.847 & 6.812 \\
\hline
\end{tabular}


Table.3 Effect of biochar, poultry manure \& sewage sludge on number of tillers in chromium contaminated soil

\begin{tabular}{|l|c|c|c|c|}
\hline Treatment & 30DAT & 60DAT & Total tiller & $\begin{array}{c}\text { Productive } \\
\text { tiller }\end{array}$ \\
\hline Cr 0 & 7.333 & 9.333 & 10.333 & 8.333 \\
\hline Cr 25 & 6.333 & 8.667 & 9.667 & 7.667 \\
\hline Cr 50 & 5.333 & 7.333 & 8.333 & 7.667 \\
\hline Cr 0 + biochar & 8.667 & 13 & 13.667 & 12.333 \\
\hline Cr 25 + biochar & 7.667 & 12 & 12.333 & 11.333 \\
\hline Cr 50+ biochar & 7.333 & 11.667 & 11.333 & 10 \\
\hline Cr 0+ PM & 8.333 & 12.333 & 12.667 & 11 \\
\hline Cr 25 + PM & 7.333 & 11.667 & 12 & 10.333 \\
\hline Cr 50+ PM & 6.667 & 10.667 & 11 & 9.333 \\
\hline Cr 0 + SS & 8 & 12.667 & 13 & 10.667 \\
\hline Cr 25 + SS & 7.333 & 11.667 & 12 & 10 \\
\hline Cr 50+ SS & 6.333 & 10.333 & 10.333 & 9 \\
\hline CD & 0.937 & 1.232 & 1.165 & 1.355 \\
\hline SE(m) & 0.319 & 0.419 & 0.397 & 0.461 \\
\hline SE(d) & 0.451 & 0.593 & 0.561 & 0.653 \\
\hline CV & 7.654 & 6.638 & 6.034 & 8.152 \\
\hline
\end{tabular}

Figure.1 Effect of biochar, poultry manure \& sewage sludge on harvest index of rice in chromium contaminated soil

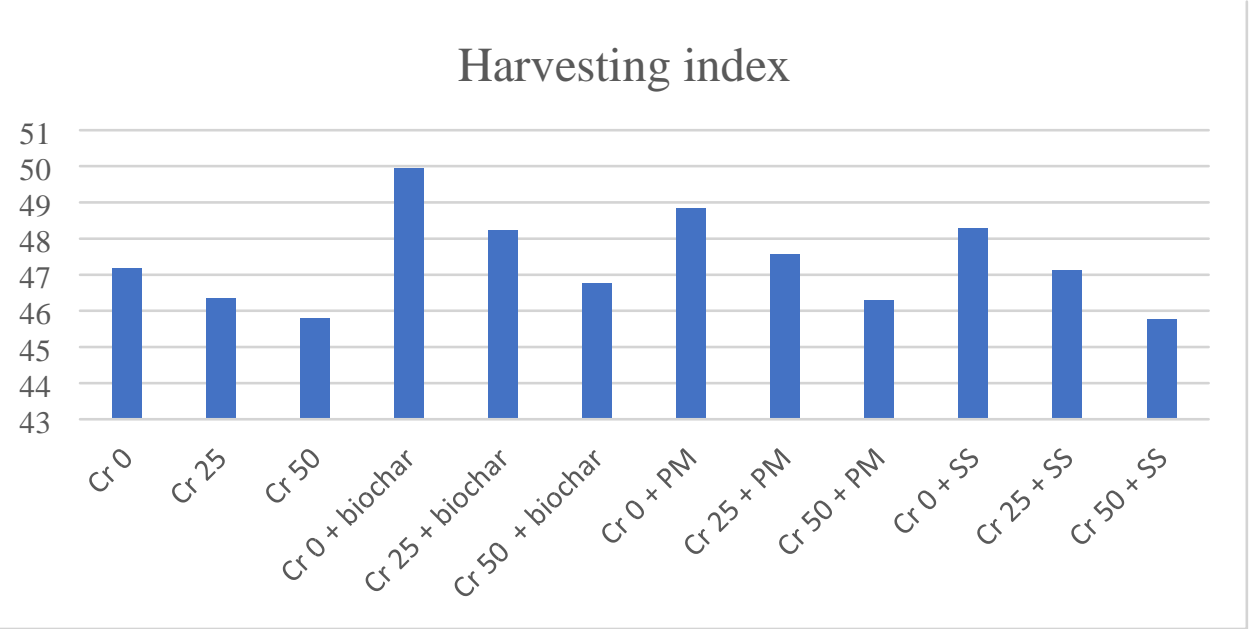


Table.4 Effect of biochar, poultry manure \& sewage sludge on yield attributes of rice in chromium contaminated soil

\begin{tabular}{|l|c|c|c|c|c|}
\hline treatment & $\begin{array}{c}\text { Panicle } \\
\text { length } \\
\text { (cm) }\end{array}$ & $\begin{array}{c}\text { No of } \\
\text { panicles } \\
\text { per m2 }\end{array}$ & $\begin{array}{c}\text { Grains } \\
\text { panicle(g } \\
\text { hil-1) }\end{array}$ & $\begin{array}{c}\text { Unfilled } \\
\text { grains/panicle } \\
\text { (g hill-1) }\end{array}$ & $\begin{array}{c}\text { Test weight } \\
\text { in g }\end{array}$ \\
\hline Cr 0 & 19.167 & 241.333 & 109 & 7 & 22.267 \\
\hline Cr 25 & 18.867 & 231.333 & 105 & 8 & 19.6 \\
\hline Cr 50 & 18.2 & 227.333 & 102 & 10 & 18.8 \\
\hline Cr 0 + biochar & 21.967 & 273.667 & 130.333 & 4 & 24.777 \\
\hline Cr 25 + biochar & 21.667 & 265.667 & 122.333 & 5.667 & 22.733 \\
\hline Cr 50 + biochar & 20.9 & 254.333 & 115 & 6.667 & 21.133 \\
\hline Cr 0 + PM & 21.1 & 267 & 125 & 5 & 23.233 \\
\hline Cr 25 + PM & 20.7 & 259.667 & 117.333 & 7 & 22.433 \\
\hline Cr 50 + PM & 20.133 & 249.333 & 112 & 7.667 & 20.8 \\
\hline Cr 0 + SS & 20.967 & 265 & 124 & 6 & 22.8 \\
\hline Cr 25 + SS & 20.733 & 259.667 & 116 & 6.667 & 21.733 \\
\hline Cr 50 + SS & 20.133 & 244 & 109.667 & 7.667 & 20.267 \\
\hline CD & 0.32 & 3.727 & 2.364 & 1.874 & 0.168 \\
\hline SE(m) & 0.109 & 1.269 & 0.805 & 0.638 & 0.057 \\
\hline SE(d) & 0.154 & 1.795 & 1.139 & 0.903 & 0.081 \\
\hline CV & 0.925 & 0.868 & 1.206 & 16.311 & 0.457 \\
\hline
\end{tabular}

Table.5 Effect of biochar, poultry manure \& sewage sludge on grain yield $\left(\mathrm{g} \mathrm{pot}^{-1}\right)$ of rice in chromium contaminated soil

\begin{tabular}{|l|l|l|l|r|r|}
\hline & $\begin{array}{l}\text { B1 } \\
\text { control }\end{array}$ & $\begin{array}{l}\text { B2 } \\
\text { Biochar }\end{array}$ & $\begin{array}{l}\text { B3 } \\
\text { Poultry } \\
\text { manure }\end{array}$ & $\begin{array}{l}\text { B4 } \\
\text { Sewage } \\
\text { sludge }\end{array}$ & Mean cr \\
\hline A1 Cr0 & 26.700 & 31.730 & 30.107 & 29.810 & 29.587 \\
\hline A2 Cr25 & 25.190 & 30.310 & 29.210 & 29.113 & 28.456 \\
\hline A3 Cr50 & 23.800 & 28.197 & 27.520 & 26.577 & 26.523 \\
\hline Mean B & 25.230 & 30.079 & 28.946 & 28.500 & \\
\hline
\end{tabular}

\begin{tabular}{|l|c|c|c|c|}
\hline Factors & C.D. & SE(d) & SE(m) & \\
\hline Factor(A) & & 0.076 & 0.054 & significant \\
\hline Factor(B) & 0.183 & 0.088 & 0.062 & significant \\
\hline Factor(A X B) & 0.317 & 0.153 & 0.108 & significant \\
\hline
\end{tabular}


Table.6 Effect of biochar, poultry manure \& sewage sludge on straw yield $\left(\mathrm{g} \mathrm{pot}^{-1}\right)$ of rice in chromium contaminated soil

\begin{tabular}{|l|l|l|l|l|l|}
\hline & $\begin{array}{l}\text { B1 } \\
\text { control }\end{array}$ & $\begin{array}{l}\text { B2 } \\
\text { Biochar }\end{array}$ & $\begin{array}{l}\text { B3 } \\
\text { Poultry } \\
\text { manure }\end{array}$ & $\begin{array}{l}\text { B4 } \\
\text { Sewage } \\
\text { sludge }\end{array}$ & Mean cr \\
\hline A1 Cr0 & 28.670 & 31.470 & 29.590 & 29.493 & 29.806 \\
\hline A2 Cr25 & 29.230 & 30.720 & 29.867 & 29.720 & 29.884 \\
\hline A3 Cr50 & 28.200 & 30.110 & 29.170 & 28.937 & 29.104 \\
\hline $\begin{array}{l}\text { Mean } \\
\text { amendment }\end{array}$ & 28.700 & 30.767 & 29.542 & 29.383 & \\
\hline
\end{tabular}

\begin{tabular}{|l|l|l|l|l|}
\hline Factors & C.D. & SE(d) & SE(m) & \\
\hline Factor(A) & 0.037 & 0.018 & 0.012 & significant \\
\hline Factor(B) & 0.042 & 0.020 & 0.014 & significant \\
\hline Factor(A X B) & 0.073 & 0.035 & 0.025 & significant \\
\hline
\end{tabular}

It is evident from the results that panicle length varied from $(21.96$ to $18.2 \mathrm{~cm})$. Among organic amendments, maximum panicle length $(21.967 \mathrm{~cm})$ was found associated with the treatment $\mathrm{Cr} 0+$ biochar which was significantly higher than the application of other amendment and control. The interaction effect between chromium levels and organic sources in respect to the length of panicle and weight of panicle was non-significant.

\section{Number of grains panicle ${ }^{-1}$}

There was a significant effect on a number of grains per panicle with a different application of different levels of chromium. A number of grains per panicle varied from (109 to $102 \mathrm{~g}$ hill-1) in case of different chromium levels in control. The highest no. of grains /panicle was seen control pots i.e., $\mathrm{Cr} 0$ followed by $\mathrm{Cr} 25$ and $\mathrm{Cr} 50$ respectively. This result shows that there was decrease in grains per panicle as the concentration of chromium increases.

It is evident from data that no. of grains /panicle varied in organic amended pots from (130.33 to $109.67 \mathrm{~g}$ hill-1). These organic amendments significantly influenced a number of grains panicle-1of rice. A maximum number of grains panicle-1 $(130.33 \mathrm{~g}$ hill1) was recorded with $\mathrm{Cr} 0+$ biochar followed by $\mathrm{Cr} 0+\mathrm{PM}$ (125) \& $\mathrm{Cr} 0+\mathrm{SS}$ (124) respectively. The addition of these organic amendments has significantly increased the number of grains panicle- 1 . The interaction effect between chromium levels and organic amendments in respect to a number of grains panicle-1 was found notsignificant.

\section{0 grains weight $(g)$}

Various chromium levels and organic amendments influence grain weight of the plant at various growth stages of the crop has been represented in Table 4.4. Data revealed that 1000 grains weight varies from $(22.26 \mathrm{~g})$ in $\mathrm{Cr} 0$ to $(18.8 \mathrm{~g})$ in $\mathrm{Cr} 50$. This data shows that increase in chromium content decreases 1000 grain weight of plant.

Different organic amendments significantly influenced 1000 grains weight of rice. Maximum 1000 grains weight $(24.77 \mathrm{~g})$ was recorded with treatment $\mathrm{Cr} 0+$ biochar followed by $\mathrm{Cr} 0+\mathrm{PM}(23.233 \mathrm{~g})$ \& $\mathrm{Cr} 0+\mathrm{SS}$ 
(22.8) respectively. The addition of these organic amendments has significantly increased the 1000 grains weight. The interaction effect between chromium levels and organic amendments in respect to 1000 grains weight was found not-significant.

All these yield attributes like panicle number, grains panicle-1, 1000 grain weight, increased with the addition of biochar \& other organic amendment as compared to control. SSBC amendments significantly increased grain yield in case of rice as reported by Khan et al., (2013). Similarly Bian et al., reported that grain yield was sustained over 3 years after a single soil amendment of wheat straw biochar. The improved growth coupled with the transport of photosynthates towards reproductive structure might have increased the yield attributes and yield due to organic addition reported by (Manivannan and Sriramachandrasekharan, 2009).

The results indicated that $\mathrm{Cr}$ affects the yield attributes of rice even though it was reported as a hyper accumulator and tolerant for heavy metals. $\mathrm{Cr}$ adversely affects the yield attributes of rice and the fertilizer amendments will alleviate the toxicity caused by $\mathrm{Cr}$ and significantly increase the yield attributes of plants.

Effect of Biochar, Poultry Manure and Sewage Sludge on grain and straw yield of rice in chromium contaminated soil

The yield of grain and straw has been depicted in the Table 5 and 6 respectively. An adverse direct effect on rice grain yield was shown by application of $\mathrm{Cr}$. The lowest value (23.37 $\mathrm{g} \mathrm{pot}^{-1}$ ) found in the treatment at $\mathrm{Cr} 50$ with a reduction in the yield by 13 per cent over control (26.7 $\left.\mathrm{g} \mathrm{pot}^{-1}\right)$. Similar results were also reported in case of the straw yield of rice due to the direct effect of $\mathrm{Cr}$ (Table6). The highest reduction in rice straw yield due to direct effect was observed at Cr50 (28.20g pot-1). The beneficial effect of $\mathrm{Cr}$ was seen at lower level up to $\mathrm{Cr} 20$ on rice which could be attributed to increased absorption of nutrients like $\mathrm{K}, \mathrm{Ca}$ and $\mathrm{Mg}$, while at very higher $\mathrm{Cr}$ concentration it might have adversely affected due to phytotoxicity. Similar results were observed by Parmar and Patel (2015). The $\mathrm{Cr}$ is inhibitory to metabolism and acts on a contributory factor in phytotoxicity of wheat (Sharma et al., 1995).

Grain yield of rice is enhanced due to the direct effect of all organic amendments over control which is shown in Table 5. Similar results were also observed in straw yield of rice due to organic amendments application reported in Table 6 . The improvement in yield of rice could be attributed to the addition of amendment like biochar, poultry manure \& sewage sludge to the soil, which increased the availability of nutrients due to enhancement in important soil properties reported by Ganal \& Singh (1988) and Singarum (1994).

The interaction effect between $\mathrm{Cr}$ and amendments like biochar, poultry manure \& sewage sludge had shown significance. The adverse effect of $\mathrm{Cr}$ on the yield of rice could be alleviated to some extent by amendment application, especially with biochar addition. Significantly, the highest rice grain yield $(31.730 \mathrm{~g})$ was recorded at treatment $\mathrm{Cr} 0$ +biochar; while the minimum yield was observed at Cr50 (23.80) without amendment (Table 5).

The grain and straw yield have been dropped after applying heavy metals which have been accredited to the toxic effects of metals on the propagation of roots and shoots. The characters of rice vary under various treatments of chromium. High organic matter and macro and micronutrients enhance both the soil physical, chemical and biological properties and the plant yield. Chatterjee and Chatterjee in 2000 found that there is decrease in biomass productivity which might be attributed due to disruption in nitrogen 
metabolism of seedlings under chromium stress Bian et al., (2014) reported significant increase in rice yield with application of wheat straw biochar.

\section{Harvest index (\%)}

Harvest index of rice affected by chromium levels and organic amendments has been compiled graphically In Fig 1. Data revealed that harvest index varies from $(47.16 \%)$ in control to $(45.8 \%)$ in $\mathrm{Cr} 50$. However, highest harvest index seen in treatment $\mathrm{Cr} 0$ is highest followed by the treatment $\mathrm{Cr} 25 \& \mathrm{Cr} 50$ respectively.

Different organic amendments significantly influenced harvest index of rice. Maximum harvest index was recorded with treatment $\mathrm{Cr} 0+$ biochar $(49.93 \%)$ followed by $\mathrm{Cr} 0+\mathrm{PM}$ $(48.83 \%)$. The addition of these organic amendments has significantly increased the harvest index. There was a significant difference in the extent of $\mathrm{Cr}$ (VI) reduction among the soils treated with organic amendments (Bolan and Thiyagarajan, 2001 and Bolan et al., 2003). Interaction effect between chromium levels and organic amendments in respect to harvest index was found non-significant

In conclusion, the present study indicated that Growth parameters like plant height, no. of tillers/hill, productive tillers /hill decreased upon increasing doses of chromium i.e., $(0,25,50 \mathrm{ppm})$. The addition of organic amendments like biochar, poultry manure \& sewage sludge has significantly increased the growth parameters of rice. The interaction found non -significant. Among treatments with organic amendments, biochar found to be more effective followed by poultry manure $\&$ sewage sludge. The results showed that growth parameters decreased in both organic amended and non-amended soils with increase in chromium concentrations. Similarly, Cr has negative impact on the yield attributes like total tillers/hill, productive tillers /hill, grains/panicle, panicle length, panicle weight, of rice. Upon increasing concentration of chromium, the yield attributes decreased respectively. Among organic treatments like biochar, poultry manure \& sewage sludge the highest values found in treatment $\mathrm{Cr} 0+$ biochar. The improved growth coupled with the transport of photosynthates towards reproductive structure might have increased the yield attributes and yield due to organic addition.

\section{References}

Adrees, M., Ali, S., Rizwan, M., Rehman, M.Z., Ibrahim, M., Abbas, F., Farid, M., Qayyum, M.K. and Irshad, M.K. Mechanisms of silicon-mediated alleviation of heavy metal toxicity in plants: a review. Ecotoxicology and Environmental Safety2015; 119: 186197.

Ahmad, M. A. Q. S. O. O. D., Wahid, A., Ahmad, S. S., Butt, Z. A. and Tariq, M. Eco physiological responses of rice (Oryza sativa L.) to hexavalent chromium. Pakistan Journal Botany2011 ;43(6): 2853-2859.

Ahmad, M., Wahid, A., Ahmad, S. S., Butt, Z. A. and Tariq, M.. Ecophysiological responses of rice (Oryza sativa L.) to hexavalent chromium. Pakistan Journal Botany2011; 43(6): 2853-2859.

Ali, Z., Malik, R.N. and Qadir, A. Heavy metals distribution and risk assessment in soils affected by tannery effluents. Chemistry and Ecology2013; 29: 676692.

Almaroai, Y.A., Usman, A.R.A., Mahtab, A., Deok, H.M., Ju-Sik, C., Young, K.J., Choong, J., Sang, S.L. and Ok, Y.S."Effects of biochar, cow bone, and eggshell on $\mathrm{Pb}$ availability to maize in contaminated soil irrigated with saline water. Environmental Earth 
Sciences2014; 71: 1289-1296.

Bian, R., Joseph, S., Cui, L., Pan, G., Li, L., Liu, X., Zhang, A., Rutlidge, H., Wong, S., Chia, C., Marjo, C., Gong, B., Munroe, P. and Donne, S.A three-year experiment confirms continuous immobilization of cadmium and lead in contaminated paddy field with biochar amendment. Journal of Hazardous Materials2014; 272: 121-128.

Bolan N.S., Adriano, D.C., Natesan, R. and Koo, B.J. Effect of organic amendments on the reduction and Phyto availability of chromate in mineral soil. Journal of Environmental Quailty2003; 32, 120128.

Bolan, N.S., Adriano, D.C., Natesan, R. and Koo, B.J. Effect of organic amendments on the reduction and phytoavailability of chromate in mineral soil. Journal of Environmental Quailty2003; 32: 120128.

Chrysochoou, M., Johnston, C.P. and Dahal, G. A comparative evaluation of hexavalent chromium treatment in contaminated soil by calcium polysulfide and green-tea nanoscale zero-valent iron. Journal of Hazardous Materials2012; 201: 33-42.

Clijsters, H. and Van Assche, F.Inhibition of photosynthesis by heavy metals.Photosynthesis Residence1985; 7: 31-40.

Dheeba, B. and Sampathkumar, P.A comparative study on the phytoextraction of five common plants against Chromium Toxicityll. Oriental Journal of Chemistry2012; 28(2): 867879.

Ganal, B. A. and Singh, C. M. Effect of farm yard manure applied in rice-wheat rotation on physico-chemical properties of soils. Indian Journal of Agronomy1988; 33(3): 327-329.

Hattab, N., Heino, M.M., Faure, O. and Bouchardon, J.L.Effect of fresh and mature organic amendments on the phytoremediation of technosols contaminated with high concentrations of trace elements. Journal of Environmental Management, Elsevier2015; 159: 37-47.

Kumpiene, J., Lagerkvist, A. and Maurice, C. Stabilization of $\mathrm{As}, \mathrm{Cr}, \mathrm{Cu}, \mathrm{Pb}$, and $\mathrm{Zn}$ in soil using amendments: A review. Waste Management2008; 28: 215-225.

Manivannan, R. and Sriramachandrasekharan, M.V. Response of lowland rice to addition of organics and mineral $\mathrm{N}$ grown on Typic Haplusterts soil. Journal of Applied Sciences Research, 2009; (11): 1988-1991.

Nagarajan, M. Effect of chromium on growth, biochemicals and nutrient accumulation of paddy (Oryza sativa L.). International Letters of Natural Sciences2014; 18.

Qiu, B., Zeng, F., Xue, D., Zhou, W., Ali, S. and Zhang, G. QTL mapping for chromiuminduced growth and zinc, and chromium distribution in seedlings of rice DH population. Euphytica2011; 181: 429-439.

Qiu, B.Y., Zhou, W.H., Xue, D.W., Zeng, F.R., Ali, S. and Zhang, G.P. Identification of Cr-tolerant lines in a rice (Oryza sativa) DH population. Euphytica2010; 174:199-207.

Ramzani, P.M.A., Khan, W.D., Iqbal, M., Kausar, S., Ali, S., Rizwan, M. and Virk, Z.A. Effect of different amendments on rice (Oryza sativa L.) growth, yield, nutrient uptake and grain quality in Ni-contaminated soil. Environmental Science and Pollution Research, 2016; DOI 10.1007/s11356016-7038-x.

Sharma, D. C., Chatterjee, C. and Sharma, C. P. Chromium accumulation and its effects on wheat (Triticum aestivum $L$. cv. HD 2204) metabolism. Plant Science, 1995; 111(2): 145-151.

Singarum, P. Effect of coil pith as an 
amendment for tannary polluted soil. Madras Agricultural Journal, 1994; 81(10): 548-549.

Usman, A.R.A., Alkredaa, R.S., and AlWabel, M.I. Heavy metal contamination in sediments and mangroves from the coast of Red Sea: Avicennia marina as potential metal bioaccumulator. Ecotoxicology and Environmental Safety 2013; 97: 263-270.

Wang, K., Gao, F., Ji, Y.X., Liu, Y., Dan, Z.W., Yang, P.F., Zhu, Y.G. and Li, S.Q. ORFH79 impairs mitochondrial function via interaction with a subunit of electron transport chain complex III in Honglian cytoplasmic male sterile rice. New Phytologist, 2013; 198: 408418.

Younis, U., Malik, S.A., Rizwan, M., Qayyum, M.F., Ok, Y.S., Shah, M.H.R., Rehman, R.A. and Ahmad, N. Biochar enhances the cadmium tolerance in spinach (Spinacia oleracea) through modification of $\mathrm{Cd}$ uptake and physiological and biochemical attributes. Environmental Science and Pollution Research, 2016; 23:2138521394. DOI 10.1007/s11356-016-73443.

Yuji Bolan, N.S. and Thiyagarajan, S. Retention and plant availability of chromium in soils as affected by lime and organic amendments. Australian Journal of Soil Research, 2001; 39: 1091-1103.

Yuji, S., Matsumoto, S. and Sadakata, M. Alkali soil reclamation with flue gas desulfurization gypsum in China and assessment of metal content in corn grains. Soil and Sediment Contamination (formerly Journal of Soil Contamination) 2004; 13(1): 65-80.

\section{How to cite this article:}

Jiten Kumar Behera, P. K. Sharma, Tusarkanta Behera, Ramya Krishna Koka and Arvind. 2020. Remediation of Chromium Toxicity by Biochar, Poultry Manure and Sewage Sludge in Rice (Oryza sativa) Crop. Int.J.Curr.Microbiol.App.Sci. 9(03): 2294-2306. doi: https://doi.org/10.20546/ijcmas.2020.903.260 